\title{
PENGEMBANGAN MEDIA PEMBELAJARAN MALONGKA (MARI LOMPAT ANGKA) DALAM MENYELESAIKAN SOAL OPEN-ENDED MATERI OPERASI BILANGAN KELAS II SD
}

\author{
Siti Nurlaili' ${ }^{1}$, Sri Hartatik ${ }^{2}$, Akhwani ${ }^{3}$, Mohammad Taufiq ${ }^{4}$ \\ 1,2,3,4 Universitas Nahdlatul Ulama Surabaya, Jl. Jemursari No 51-57 Surabaya \\ 4130016022@student.unusa.ac.id
}

\begin{abstract}
This study aims to develop the traditional game of the ankle into a learning medium. The developed media is named Malongka (let's jump in numbers) number operations. The development of this media in terms of process, quality, and effectiveness of its use. The method used in this research is research and development (R\&D). the steps used are the Sugiyono and Borg and Gall models. These steps are modified into six stages of development, namely: finding potentials and problems, compiling plans, making product designs, conducting product validations, product revisions, and product trials. The product trials were carried out on a small scale to six grade II students at Hidayatur Rohman Elementary School in 2019/2020 Academic Year. The results of this study are. (1) this media has aspects, such as: interesting, fun, and fostering students' creativity (2) The quality of Malongka media for Operation Numbers has a "very good" quality with an average score of 3.3. (3) Student test results after getting learning using Malongka media in solving open ended questions related to Operation Numbers increased by $128.2 \%$ and students were more active in following the learning process.
\end{abstract}

Keywords: R\&D, Malongka, Open Ended, Number Operations.

\begin{abstract}
Abstrak
Penelitian ini bertujuan untuk mengembangkan permainan tradisional engkle menjadi media pembelajaran. Media yang dikembangkan diberi nama Malongka (mari lompat angka) operasi bilangan. Pengembangan media ini ditinjau dari segi proses, kualitas, dan efektivitas penggunaannya. Metode yang digunakan dalam penelitian ini adalah penelitian dan pengembangan $(R \& D)$. langkah-langkah yang digunakan adalah model Sugiyono serta Borg dan Gall. Langkah-langkah tersebut dimodifikasi ke dalam enam langkah pengembangan, yaitu: mencari potensi dan masalah, menyusun perencanaan, membuat desain produk, melakukan validasi produk, revisi produk, dan uji coba produk. Uji coba produk dilakukan secara skala kecil kepada enam siswa kelas II SD Hidayatur Rohman Surabaya Tahun Ajaran 2019/2020. Hasil dari penelitian ini adalah. (1) media ini mempunyai aspek, antara lain: menarik, menyenangkan, dan menumbuhkan kreativitas siswa (2) Kualitas media Malongka Operasi Bilangan memiliki kualitas yang "sangat baik" dengan rata-rata skor 3,3. (3) Hasil tes siswa setelah mendapatkan pembelajaran dengan menggunakan media Malongka dalam menyelesaikan soal open ended terkait Operasi Bilangan mengalami kenaikan sebesar 128,2\% serta siswa lebih aktif dalam mengikuti proses pembelajaran.
\end{abstract}

Kata kunci: $R \& D$, Malongka, open ended, operasi bilangan.

\section{PENDAHULUAN}

Malongka merupakan media berbentuk permainan dengan fungsi untuk mengasah kreativitas siswa dalam menyelesaikan soal open-ended. Media malongka dikembangkan dari permainan tradisional engklek bertujuan untuk mengembangkan kecerdasan logika anak, yaitu melatih anak untuk berhitung dan menentukan langkah-langkah yang harus dilewatinya (Achroni, 2012: 5). Permainan tradisional merupakan permainan yang memberikan manfaat untuk perkembangan anak yang terdapat kekayaan bangsa dan refleksi budaya (Iswinarti, 2010). Permainan engklek sebelumnya menggunakan bidang atau arena bermain yang berbentuk gunung atau pesawat. Media malongka ini 
menggunakan banner berbentuk persegi terdiri dari 6 kotak ke samping dan 4 kotak ke bawah dengan masing-masing berukuran $30 \mathrm{~cm}$ x $30 \mathrm{~cm}$ dengan menggunakan lingkaran angka.

Keterkaitan media pembelajaran malongka dalam menyelesaikan soal open-ended materi operasi bilangan yaitu, kegiatan permainan malongka memberikan siswa kesempatan untuk berinteraksi secara langsung. Dalam permainan ini juga mengasah kreativitas siswa karena dihadapkan pada berbagai macam lingkaran angka dan kartu soal open-ended. Media pembelajaran malongka dapat menyelesaikan soal open-ended pada materi operasi bilangan.

Tujuan penerapan pembelajaran open-ended dalam proses pembelajaran adalah untuk mengembangkan kemampuan berpikir siswa, agar lebih kreatif dalam mengembangkan strategi atau cara penyelesaian menggunakan kemampuan mereka sendiri (Isrok'atun, 2019 :82). Setiap siswa mempunyai karakteristik berbeda terkait aktivitas penyelesaian masalah. Pembelajaran matematika perlu dirancang sedemikian sehingga dapat mengakomodasi berbagai ragam karakteristik siswa. Salah satu cara yang dapat mewujudkan hal itu adalah penggunaan soal terbuka dalam pembelajaran matematika. Karakteristik soal terbuka memungkinkan siswa untuk menyelesaikan masalah dengan cara yang mereka pilih.

Pendekatan soal open-ended merupakan suatu pendekatan pembelajaran yang dikembangkan oleh Becker dan Shimada (Lestari, K.E. dan Yudhanegara, 2015 :41) dalam tulisannya yang berjudul The Open-Ended Approach: A New for Teaching Mathematics. Open-Ended adalah suatu pendekatan pembelajaran dengan menyajikan suatu permasalahan yang memiliki lebih dari satu jawaban dan atau metode penyelesaian (masalah terbuka). Masalah yang bersifat terbuka ini merupakan tantangan bagi siswa dimana untuk menyelesaikannya siswa harus bisa mencari pola penyelesaian masalah, menemukan solusi, dan menafsirkan penyelesaian masalah. Hal ini akan memberikan kesempatan kepada siswa untuk menjawab soal dengan caranya sendiri namun tetap benar.

Menurut Nohdah (Khoriyani, 2019) dasar keterbukaan dalam masalah terbuka dapat diklasifikasikan dalam tiga tipe, yakni: process is open (prosesnya terbuka), end product are open (hasil akhir yang terbuka), dan ways to develop are open (cara pengembang lanjutannya terbuka. Adapun pada penelitian ini digunakan dasar keterbukaan proses process is open (prosesnya terbuka) dikarenakan akan dilihat kemampuan siswa dalam menyelesaikan soal terkait operasi bilangan yang memiliki banyak penyelesaian dengan menggunakan media pembelajaran.

Melalui hasil wawancara dengan siswa kelas II mengalami kesulitan dalam memahami pelajaran matematika. Materi matematika yang dianggap sulit adalah pembagian bersusun. Salah satu siswa berkata, "Matematika itu rumit." Siswa yang lain juga mengatakan bahwa guru hanya menjelaskan materi melalui papan tulis dan buku saja kemudian mengerjakan soal-soal dan tidak menggunakan media atau permainan-permainan dalam pembelajaran. Siswa mengatakan bahwa ketika di dalam pembelajaran guru menggunakan media atau permainan, siswa akan merasa lebih tertarik dan antusias ketika belajar. 
Berdasarkan permasalahan di atas, dibutuhkan pengembangan media pembelajaran berupa permainan malongka. Malongka terkait operasi bilangan berbentuk persegi dengan ukuran panjangnya $210 \mathrm{~cm}$ dan lebarnya $195 \mathrm{~cm}$. Malongka ini dibuat dengan menggunakan aplikasi CorelDRAW 2019 kemudian di cetak menjadi banner. Pada banner malongka ini terdiri dari tempat tulisan malongka berukuran $180 \mathrm{~cm}$ x $15 \mathrm{~cm}$, tempat tulisan hasil berukuran $180 \mathrm{~cm}$ x $30 \mathrm{~cm}, 6$ kotak ke samping dan 4 kotak ke bawah dengan masing-masing berukuran $30 \mathrm{~cm}$ x $30 \mathrm{~cm}$.

Pengembangan media malongka matematika pada materi operasi bilangan diharapkan dapat membantu siswa dalam menyelesaikan soal open-ended dengan berbagai cara penyelesaian jawaban yang benar. Malongka merupakan sebuah media yang berbentuk permainan dengan fungsi untuk mengasah kreativitas siswa.

\section{METODE}

Metode yang digunakan dalam penelitian ini adalah penelitian dan pengembangan (R\&D). Penelitian pengembangan adalah metode penelitian yang digunakan untuk menghasilkan produk tertentu dan menguji keefektifan produk tersebut (Sugiyono, 2016: 407). Menurut Borg dan Gall (Suharmanto, 2015) menyatakan bahwa penelitian pengembangan adalah suatu proses atau langkahlangkah untuk mengembangkan suatu produk baru atau menyempurnakan produk yang telah ada yang dapat dipertanggungjawabkan. Langkah-langkah yang digunakan adalah model Sugiyono serta Borg dan Gall. Model pengembangan yang pertama yaitu langkah-langkah penelitian (R\&D) menurut (Sugiyono, 2016: 409) ada sepuluh langkah dalam penelitian dan pengembangan tersebut sebagai berikut:

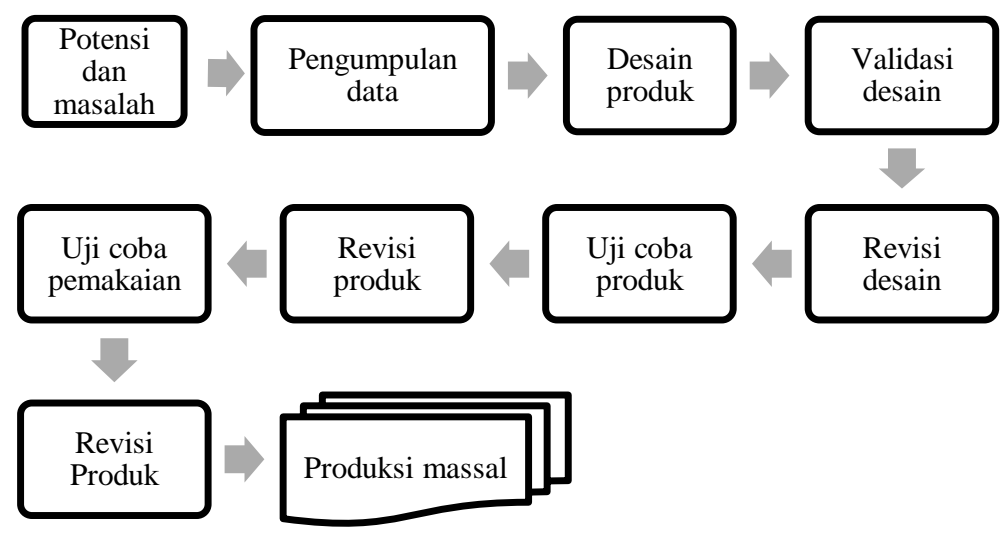

Bagan 1. Langkah-langkah penggunaan penelitian dan pengembangan menurut Sugiyono

Model pengembangan yang kedua yaitu langkah-langkah penelitian pengembangan ( $R \& D$ ) menurut Borg dan Gall (Zainal, 2012: 129), disusun dalam sepuluh langkah pelaksanaan strategi penelitian dan pengembangan, dapat dilihat pada Bagan 2. 


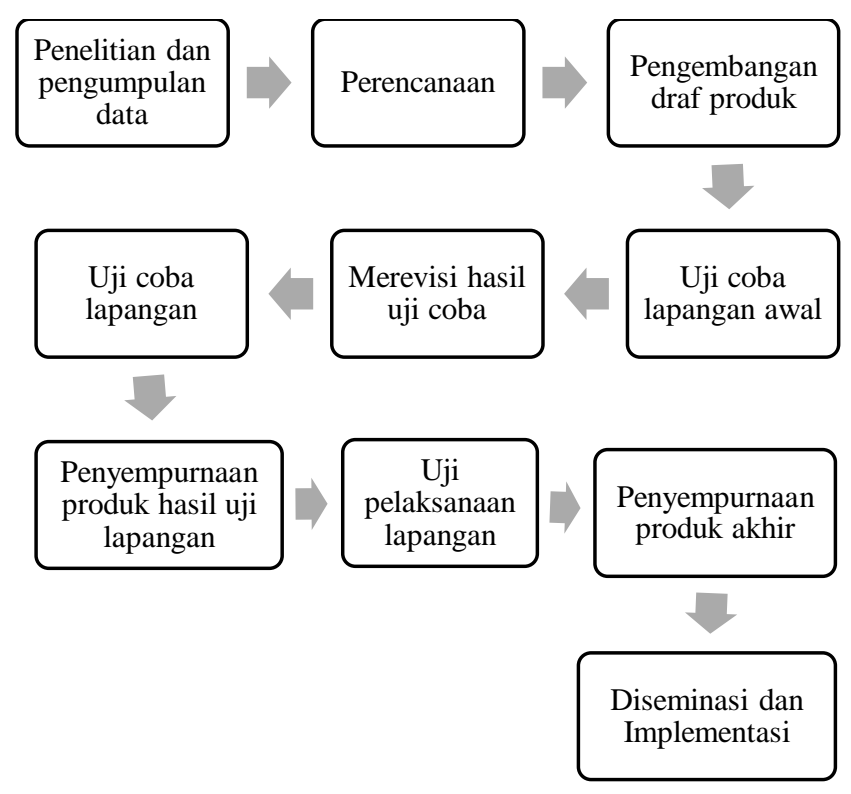

Bagan 2. Langkah-Langkah Penelitian dan Pengembangan Menurut Borg Dan Gall

Langkah-langkah tersebut dimodifikasi ke dalam enam langkah pengembangan, yaitu: mencari potensi dan masalah, menyusun perencanaan, membuat desain produk, melakukan validasi produk, revisi produk, dan uji coba produk. Uji coba produk dilakukan secara skala kecil kepada enam siswa kelas II SD Hidayatur Rohman Surabaya Tahun Ajaran 2019/2020. Bagan 3 menunjukkan langkah-langkah dari modifikasi tersebut.

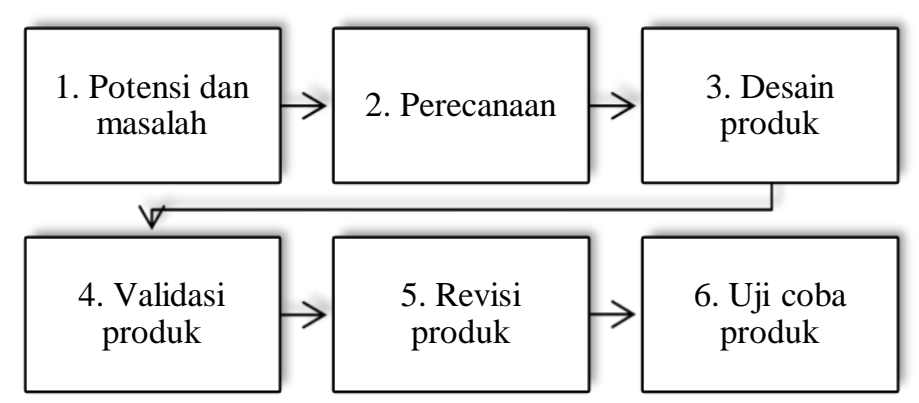

Bagan 3. Langkah-Langkah Modifikasi Pengembangan

Langkah pertama peneliti yaitu mencari permasalahan yang ada pada pembelajaran matematika di kelas II melalui wawancara dan observasi. Kedua, perencanaan yaitu membuat beberapa instrumen yang digunakan dalam penelitian seperti tes dan kuesioner analisis kebutuhan terkait media yang dibutuhkan dan kuesioner validasi produk dalam tahap ini. Langkah ketiga yang dilakukan peneliti yaitu desain produk. Selanjutnya langkah keempat yang dilakukan peneliti yaitu validasi produk. Langkah kelima yautu revisi produk, dari hasil validasi produk yang dilakukan oleh para ahli. Tahap yang terakhir yaitu uji coba produk. Setelah produk diperbaiki, kemudian peneliti melakukan uji coba produk yaitu uji coba produk dalam skala kecil diambil hanya 6 siswa terdiri dari 4 perempuan dan 2 laki-laki siswa kelas II SD Hidayatur Rohman Surabaya. 
Tenknik pengumpulan data yang digunakan yaitu wawancara terhadap guru dan siswa kelas II, observasi kelas untuk mengamati metode mengajar yang digunakan guru, penggunaan media pembelajaran, dan keaktifan siswa di dalam pembelajaran. Observasi juga dilakukan selama uji coba produk bertujuan untuk mendapatkan data tentang efektivitas penggunaan media Malongka. Kuesioner digunakan untuk mengumpulkan data terkait analisis kebutuhan terhadap media yang dibutuhkan di sekolah serta validasi terhadap produk yang dibuat. Tes dalam penelitian ini menggunakan soal pretest dan posttest untuk mengetahui keefektifan media dalam pembelajaran.

\section{HASIL}

Hasil penelitian berisi tentang kajian kompetensi dasar pembelajaran, analisis kebutuhan, produksi pengembangan media malongka terkait operasi bilangan, validasi dan revisi produk, dan uji coba lapangan skala kecil. Berikut adalah uraian dari kelima tahap tersebut.

\section{Kajian Kompetensi Dasar Pembelajaran}

Penelitian ini dilaksanakan di SD Hidayatur Rohman Surabaya. Materi operasi bilangan memiliki kompetensi dasar yaitu: (4.4) yang berbunyi "Mengurai sebuah bilangan asli sampai dengan 500 sebagai hasil penjumlahan, pengurangan, perkalian atau pembagian dengan dua buah bilangan asli lainnya dengan berbagai kemungkinan jawaban". Hasil analisis kajian kompetensi dasarnya yaitu siswa melakukan operasi hitung bilangan asli dengan benar dan menyelesaikan operasi hitung bilangan asli menggunakan soal open-ended. Di mana siswa dapat menyelesaikan soal open-ended terkait operasi bilangan dengan berbagai cara penyelesaiannya.

\section{Analisis Kebutuhan}

Analisis kebutuhan yang peneliti lakukan antara lain: wawancara kepada guru dan 5 siswa kelas II SD, observasi pembelajaran di kelas II SD, dan kuesioner analisis kebutuhan yang diberikan kepada guru dan siswa kelas II SD.

\section{Wawancara Kepada Guru dan 6 Siswa Kelas II SD}

Hasil dari wawancara kepada guru bahwa siswa kelas II masih kesulitan materi perkalian dan pembagian terutama dalam menyelesaikan soal open-ended. Untuk mengatasi kesulitan belajar siswa tersebut, guru hanya memberikan soal saja. Untuk hasil wawancara terhadap siswa bahwa guru kurang memberikan soal open-ended. Ketika di kelas, guru tidak ada yang menggunakan media hanya menjelaskan melalui metode ceramah serta buku saja.

\section{Observasi Pembelajaran di Kelas II}

Berdasarkan observasi pembelajaran kelas II tersebut diperoleh hasil bahwa pembelajaran di kelas II tersebut belum adanya penggunaan media di dalam proses pembelajaran berlangsung. Ketika guru bertanya materi yang diberikan, siswa masih dibantu oleh guru untuk menjawab pertanyaan, masih terlihat bingung, dan kebanyakan hanya pasif dan diam di tempat/dibangkunya. 


\section{Kuesioner Analisis Kebutuhan oleh Guru dan Siswa Kelas II}

Dari hasil pengisian kuesioner analisis kebutuhan oleh guru, dapat disimpulkan bahwa media yang dibuat harus dapat mudah digunakan, siswa belajar secara mandiri, siswa tahu kesalahannya, sesuai dengan kemampuannya dan menumbuhkan rasa minat belajar siswa. Hasil pengisian kuesioner analisis kebutuhan oleh siswa, dapat disimpulkan bahwa siswa senang belajar dengan menggunakan media. Media yang menarik dari bahan maupun warnanya, dapat digunakan siswa secara mandiri, sesuai dengan kemampuan siswa, dan mudah. Selain itu, biayanya murah dan beratnya sedang menjadi jawaban terbanyak dari siswa kelas II.

\section{Produksi Pengembangan Media Malongka Terkait Operasi Bilangan}

\section{Desain Media Pembelajaran}

Malongka terkait operasi bilangan berbentuk persegi dengan ukuran panjangnya $210 \mathrm{~cm}$ dan lebarnya $195 \mathrm{~cm}$. Pada banner Malongka ini terdiri dari tempat tulisan Malongka berukuran $180 \mathrm{~cm} \mathrm{x}$ $15 \mathrm{~cm}$, tempat tulisan hasil berukuran $180 \mathrm{~cm}$ x $30 \mathrm{~cm}, 6$ kotak ke samping dan 4 kotak ke bawah dengan masing-masing berukuran $30 \mathrm{~cm}$ x $30 \mathrm{~cm}$. Masing-masing kotak diberi gambar berbentuk kaki sesuai dengan fungsi medianya yaitu lompat angka, di bagian tengah gambar kaki ada lingkaran berdiameter $12 \mathrm{~cm}$ berfungsi untuk tempat angka dan tempat tulisan start berukuran $180 \mathrm{~cm} \times 30 \mathrm{~cm}$. Di bagian sebelah kiri terdapat tempat simbol operasi hitung terdiri dari +, -, $\mathrm{x}$ dan : diberi warna hitam.

Setiap simbol operasi hitung berukuran $30 \mathrm{~cm}$ x $30 \mathrm{~cm}$, terdapat 10 lingkaran yang berisi angka $0,1,2,3,4,5,6,7,8$, dan 9. Setiap angka terdiri dari 12 lingkaran angka. Jadi, total lingkaran angka seluruhnya ada 120 lingkaran angka. Masing-masing angka diberi warna sesuai dengan fungsi dan nilai tempatnya, yaitu: angka warna biru (ribuan), angka warna merah (ratusan), angka warna kuning (puluhan), dan angka warna hijau (satuan).

Kartu soal berisikan soal open-ended terkait pejumlahan, pengurangan, perkalian, dan pembagian supaya diselesaikan oleh siswa. Kartu soal berukuran $8 \mathrm{~cm}$ x $4 \mathrm{~cm}$. Pada bagian depan kartu soal ada terdapat soal open-ended, angka yang digunakan dalam kartu soal dibuat berwarna sesuai nilai dan tempatnya supaya memudahkan siswa ketika melakukan perhitungan. Di bagian atas kartu soal terdapat bagian yang berfungsi sebagai tempat kode soal. Tempat kode soal berukuran $2 \mathrm{~cm}$ x $1 \mathrm{~cm}$. Tulisan kode soal dibuat berwarna hitam. Kode soal yang digunakan ada 4, yaitu: (1) penjumlahan, (2) pengurangan, (3) perkalian, dan (4) pembagian. Setiap kode soal terdiri dari 10 kartu soal. Jadi, total kartu soal seluruhnya ada 40 kartu soal.

\section{Pembuatan Media Pembelajaran}

Pembuatan media banner malongka, simbol operasi hitung, dan lingkaran angka menggunakan bantuan aplikasi CorelDRAW 2019, pada banner malongka dibuat gambar kaki lucu berwarna biru untuk menarik perhatian siswa dan petak yang berbentuk kotak untuk melompat. Kartu 
Pengembangan Media Pembelajaran Malongka (Mari Lompat Angka) Dalam Menyelesaikan Soal Open-Ended Materi Operasi Bilangan Kelas II SD, Siti Nurlaili, Sri Hartatik, Akhwani, Mohammad Taufiq

soal dibuat dengan menggunakan bantuan aplikasi Microsoft Word 2013. Hasil desain setelah direvisi oleh ahli media terlihat pada Gambar di bawah.

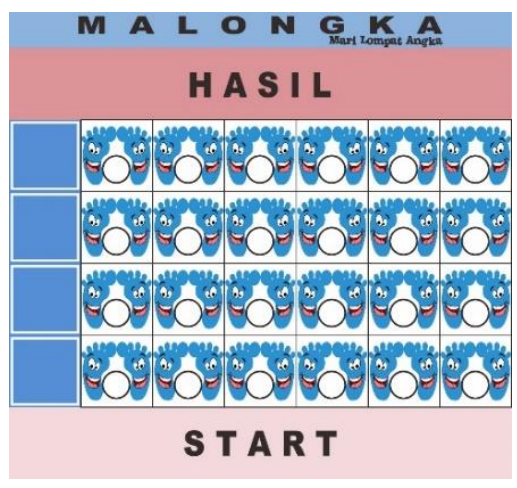

Gambar 1. Banner Malongka Operasi Bilangan Setelah Revisi Oleh Ahli Media

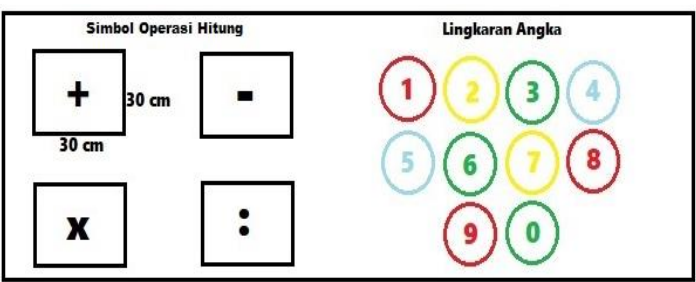

Gambar 2. Desain Simbol Operasi Hitung dan Lingkaran Angka

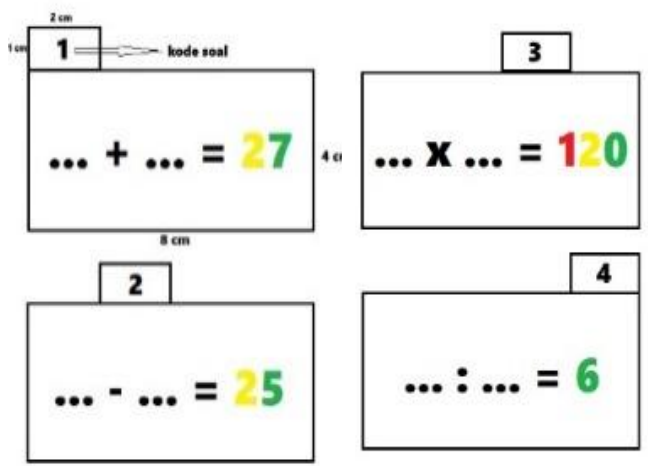

Gambar 3. Kartu soal

\section{Buku Petunjuk Permainan Malongka}

Buku petunjuk media pembelajaran malongka dibuat dengan bantuan aplikasi Microsoft Word 2013. Cover buku dan langkah-langkah penggunaan media dilengkapi dengan gambar-gambar yang sudah diedit kemudian diedit rapi sesuai dengan informasi yang ditunjukkannya. Buku petunjuk media pembelajaran malongka operasi bilangan dicetak di kertas HVS ukuran A5 dan dijilid. Hasil desain buku petunjuk dapat dilihat pada Gambar 4 . 
\ิ:

(i)

Langkah-langkah penggunaan media malongka

1. Guru menjelaskan bahwa proses pembelajaran menggunakan model pembelajaran open ended dengan berkata, "Kita menggunakan pembelajaran open ended yang di maksud pembelajaran open ended adalah cara penyelesaian/mengerjakan soal menggunakan kemampuan kalian sendiri dan memiliki jawaban benar lebih dari satu jawaban, Ibu beri contoh ... +...= 20 (berapa di tambah berapa hasilnya 20), pasti kalian mempunyai jawaban yang beragam ada yang menjawab:

$10+10=20$

$11+9=20$

$12+8=20$

$13+7=20$

$14+6=20$

$15+5=20$

$16+4=20$

(ii)

soal. Soal-soal penjumlahan dapat dilihat di kartu soal dengan kode soal 1, soal-soal pengurangan dapat dilihat di kartu soal dengan kode soal 2 , soal-soal perkalian dapat dilihat di kartu soal dengan kode soal 3, dan soal-soal pembagian dapat dilihat di kartu soal dengan kode soal 4.

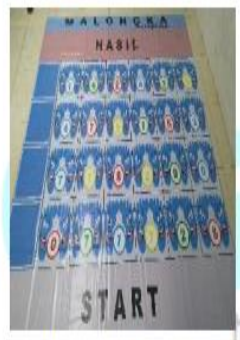

3) Yang ketiga, pemain melompat dengan satu kaki untuk mengambil lingkaran angka. Mulai dari start sampai kotak angka, sesuai dengan petunjuk kartu soal.

\section{$17+3=20$}

masih banyak lagi proses penyelesciannya dengan jawaban yang benar."

2. Guru menjelaskan cara bermain malongka dengan berkata, "Nah, ada beberapa cara permainan malongka, yaitu:"

1) Pertama, Semua pemain melakukan hompimpa yang menang berhak melakukan permainan terlebih dahulu.

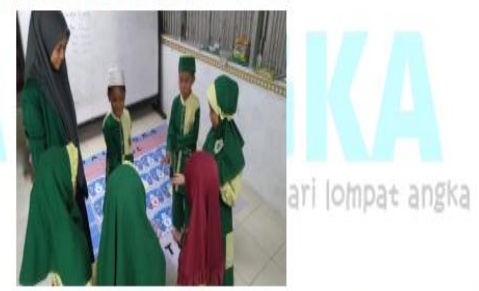

2) Yang kedua, Sebelumnya guru meletakkan lingkaran angka secara acak pada media malongka, pemain mengambil kode soal dan simbol operasi hitung yang ada di tempat/wadah bilangan, sesuai dengan petunjuk kartu

4) Yang keempat, Kemudian lompat lagi dengan satu kaki sampai pada kotak hasil yang ditentukan.

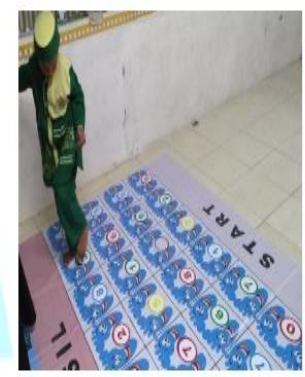

5) Yang kelima, Apabila pemain tidak dapat menjawab maka dianggap gugur dan diganti oleh pemain berikutnnya.

6) Siswa yang mendapatkan poin lebih banyak adalah pemenangnya.

7) Catatan: Pergiliran dilakukan jika pemain mengambil angka dan lambang bilangan melewati sasaran, atau menampak dua kaki pada kotak dan berhenti sejenak kemudian lompat lagi sampai pada kotak hasil.

Gambar 4. Tampilan Buku Petunjuk Permainan Malongka

\section{Prototipe Media Pembelajaran}

Prototipe dalam penelitian ini adalah prototipe media pembelajaran matematika untuk siswa kelas II SD materi penjumlahan, penguranga, perkalian, dan pembagian. Berikut ini adalah komponen-komponen prototipe media pembelajaran malongka operasi bilangan. 

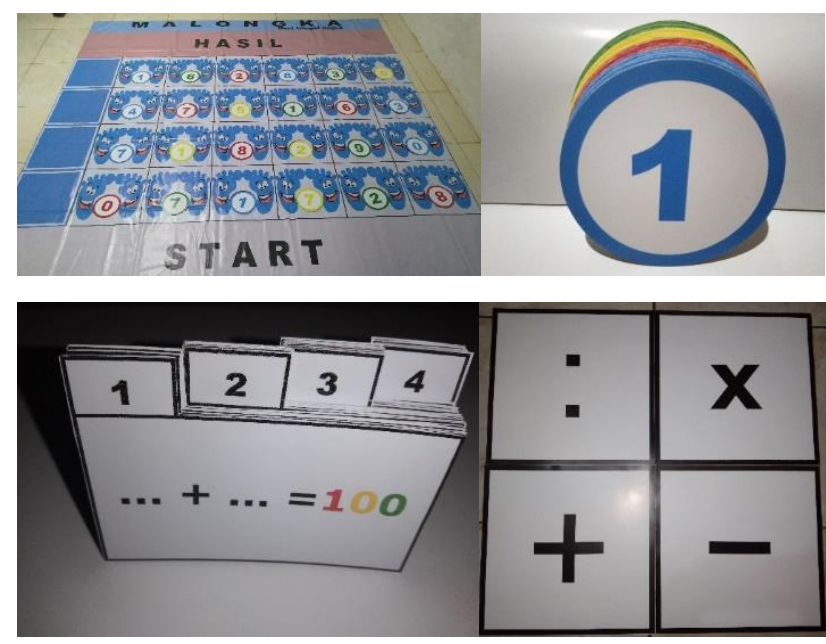

Gambar 5. Produk Penelitian dan Pengembangan Secara Lengkap

\section{Validasi dan Revisi Produk}

\section{Validasi Ahli}

Media pembelajaran malongka divalidasi oleh validator. Proses validasi menggunakan instrumen yang telah disiapkan dan telah disetujui oleh dosen pembimbing. Lembar validasi media terdiri dari 5 aspek dan 10 indikator. Melakukan validasi produk kepada dosen ahli di bidangnya (dosen mata kuliah matematika PGSD Universitas Nahdlatul Ulama Surabaya) dan guru kelas II SD Hidayatur Rohman Surabaya.

\section{Hasil Validasi}

Melalui validasi produk tersebut, dapat mengetahui kualitas serta kekurangan yang ada pada produk yang dikembangkan tersebut. Dengan, demikian dapat memperbaiki pengembangan produk tersebut dan pada akhirnya menghasilkan suatu produk berkualitas baik. Aspek media malongka operasi bilangan terdiri dari 10 indikator berupa instrumen kuesioner yang terdiri dari aspek kelengkapan materi, aspek pembuatan, aspek soal, aspek petunjuk permainan, dan aspek penggunaan. Hasil validasi produk oleh dosen ahli dan guru kelas II dapat dilihat pada Tabel 1.

\section{Tabel 1.}

Validasi Ahli Media

\begin{tabular}{|l|l|l|}
\hline Validator & Skor & Kategori \\
\hline Dosen Ahli & 3,4 & Sangat Baik \\
\hline Guru Kelas II & 3,2 & Sangat Baik \\
\hline Rata-rata & 3,3 & Sangat Baik \\
\hline
\end{tabular}

Berdasarkan hasil validasi media, bahwa skor rata-rata yang diperoleh validasi media yaitu sebesar 3,3. Hal ini menunjukkan bahwa media malongka operasi bilangan sudah termasuk sangat baik. Meskipun untuk media sudah sangat baik, peneliti mendapatkan saran dari validator yang akan 
digunakan peneliti untuk memperbaiki produk yang peneliti hasilkan. Dengan demikian, produk yang dihasilkan dapat berkualitas lebih baik lagi. Saran dari validator sebagai berikut:

\section{Tabel 2.}

Saran Validator dalam Validasi Produk

\begin{tabular}{|c|c|c|}
\hline Validator & Saran & Sebelum Revisi \\
\hline \multirow[t]{2}{*}{ Dosen Ahli } & $\begin{array}{l}\text { Menyediakan tempat pada } \\
\text { banner malongka, untuk } \\
\text { menandakan tempat angka. }\end{array}$ & 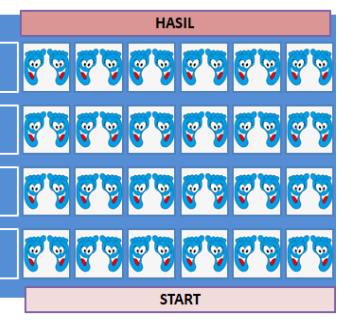 \\
\hline & $\begin{array}{l}\text { Angka tidak permanen, jadi } \\
\text { bisa dilepas. }\end{array}$ & 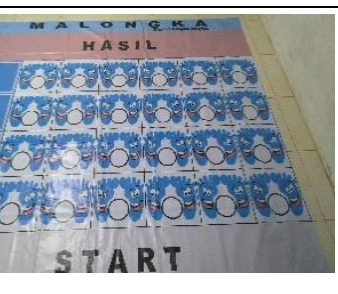 \\
\hline Guru Kelas II & $\begin{array}{l}\text { Membedakan antara angka } \\
\text { untuk satuan, puluhan, } \\
\text { ratusan, dan ribuan. }\end{array}$ & \\
\hline
\end{tabular}

\section{Revisi Produk}

Revisi produk, terdapat beberapa saran terhadap pengembangan produk yang dihasilkan. Saran tersebut digunakan untuk merevisi produk yang akan dihasilkan. Dengan demikian, produk yang dihasilkan dapat menjadi lebih berkualitas. Saran dan Tindak lanjut diuraikan pada Tabel 3.

\section{Tabel 3.}

Saran dan Tindak Lanjut

\begin{tabular}{|l|l|c|}
\hline \multicolumn{1}{|c|}{ Saran } & \multicolumn{1}{|c|}{ Tindak Lanjut } & Sesudah Revisi \\
\hline $\begin{array}{l}\text { Menyediakan tempat pada } \\
\text { banner malongka, untuk } \\
\text { menandakan tempat angka. }\end{array}$ & $\begin{array}{l}\text { Memberi lingkaran ditengah } \\
\text { gambar kaki lucu pada banner } \\
\text { malongka untuk tempat angka. }\end{array}$ & M A L N I L \\
& & H.KA \\
& & S T A T T \\
\hline
\end{tabular}




\begin{tabular}{|l|l|l|}
\hline $\begin{array}{l}\text { Angka tidak permanen, jadi } \\
\text { bisa dilepas. }\end{array}$ & $\begin{array}{l}\text { Lingkaran angka tidak } \\
\text { permanen, jadi bisa dilepas } \\
\text { pasang. }\end{array}$ \\
\hline $\begin{array}{l}\text { Membedakan antara angka } \\
\text { untuk satuan, puluhan, } \\
\text { ratusan, dan ribuan. }\end{array}$ & $\begin{array}{l}\text { Memberi warna pada lingkaran } \\
\text { angka yaitu warna hijau untuk } \\
\text { satuan, warna kuning untuk } \\
\text { puluhan, warna merah untuk } \\
\text { ratusan, dan warna biru untuk } \\
\text { ribuan. }\end{array}$ \\
\hline
\end{tabular}

\section{Uji Coba Lapangan Skala Kecil}

Uji coba lapangan skala kecil pada enam siswa (2 laki-laki dan 4 perempuan) kelas II SD Baitur Rohman yang mendapatkan nilai matematika rendah terkait materi operasi bilangan. Selama uji coba lapangan terbatas dilaksanakan, siswa diberi pendampingan untuk menggunakan pengembangan media pembelajaran yang dihasilkan. Sebelumnya, diadakan pretest kepada enam siswa tersebut untuk mengetahui kemampuan awal siswa. Setelah diberi pendampingan siswa mengerjakan posttest untuk mengetahui kemampuan mereka terhadap soal open-ended materi penjumlahan, pengurangan, perkalian dan pembagian menggunakan media pembelajaran. Soal pretest dan posttest terdiri dari 5 soal open-ended penjumlahan, 5 soal open-ended pengurangan, 5 soal open-ended perkalian, dan 5 soal open-ended pembagian. Setelah melakukan pretest, uji coba lapangan skala kecil, dan posttest selajutnya peneliti melakukan analisis terhadap hasil penelitian yang didapatkan. Analisis yang dilakukan yaitu perbedaan nilai yang didapatkan siswa sebelum belajar menggunakan media pembelajaran dan sesudah belajar menggunakan media pembelajaran. Berikut ini adalah perbedaan hasil pretest dan posttest enam siswa yang menjadi subjek di dalam uji coba lapangan skala kecil.

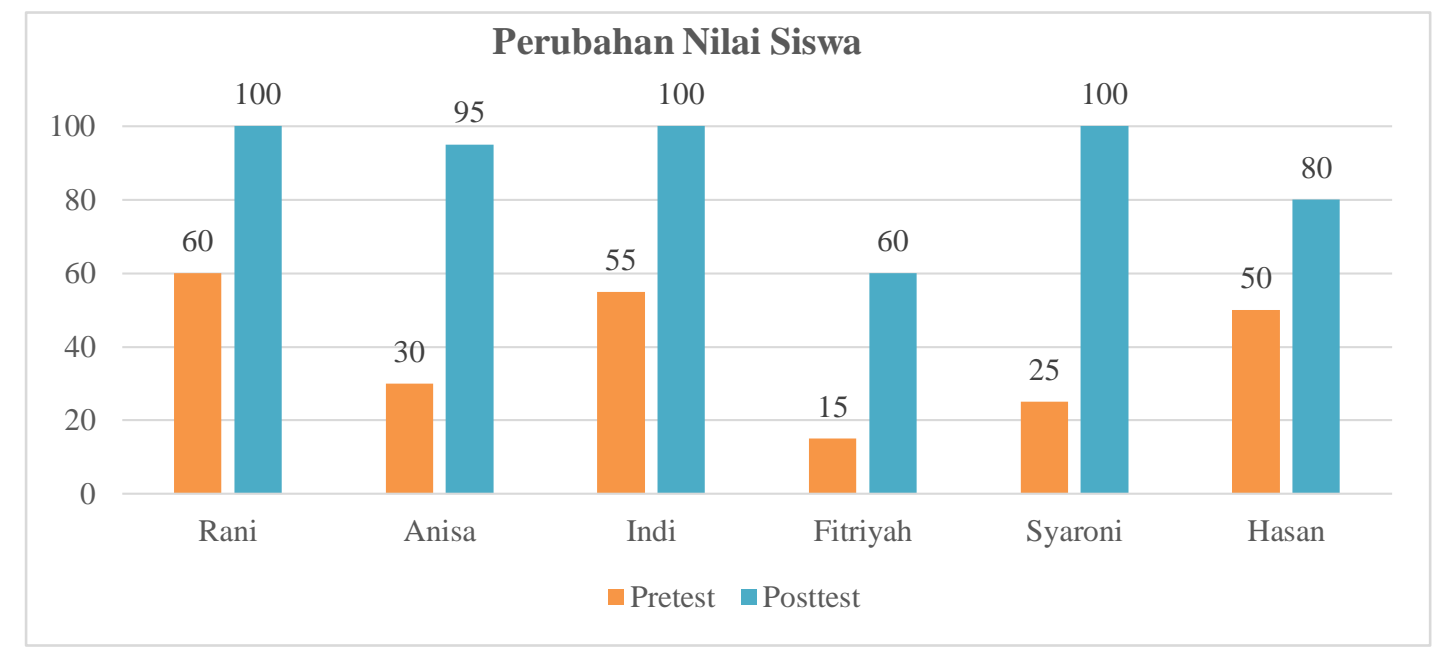

Gambar 6. Perubahan Nilai Siswa 
Dari Gambar 6. siswa mengalami kenaikan terhadap nilai tes sebelum menggunakan media pembelajaran (pretest) dan sesudah menggunakan media pembelajaran (posttest). Untuk mengetahui presentase kenaikan nilai siswa dapat digitung dengan menggunakan rumus sebagai berikut:

$$
\text { Persentase kenaikan }=\frac{\text { nilai } \text { posttest }- \text { nilai } \text { pretest }}{\text { nilai } \text { pretest }} \times 100 \%
$$

Berikut ini presentase kenaikan antara hasil pretest dan posttest yang diperoleh siswa pada tabel di bawah ini:

\section{Tabel 4.}

Presentase Kenaikan Antara Hasil Pretest dan Posttest

\begin{tabular}{|c|c|c|c|c|c|}
\hline No. & Nama & Pretest & Posttest & Kenaikan & Presentase Kenaikan \\
\hline 1. & Rani & 60 & 100 & 40 & $66,7 \%$ \\
\hline 2. & Anisa & 30 & 95 & 65 & $216,7 \%$ \\
\hline 3. & Indi & 55 & 100 & 45 & $81,8 \%$ \\
\hline 4. & Fitriyah & 15 & 60 & 45 & $300 \%$ \\
\hline 5. & Syaroni & 25 & 100 & 75 & $300 \%$ \\
\hline 6. & Hasan & 50 & 80 & 30 & $60 \%$ \\
\hline \multicolumn{2}{|c|}{ Rata-rata } & 39 & 89 & 50 & $128,2 \%$ \\
\hline
\end{tabular}

Dari tabel 4 dapat dilihat bahwa rata-rata pretest siswa hanya diperoleh skor 39 sedangkan pada rata-rata hasil posttest siswa terdapat kenaikan skor menjadi 89. Berdasarkan presentase kenaikannya, terjadi peningkatan sebesar $128,2 \%$ dari rata-rata keenam siswa tersebut setelah mendapatkan pembelajaran dengan menggunakan media pembelajaran. Dan dapat dilihat juga bahwa perbedaan antara nilai pretest dan posttest masing-masing cukup tinggi.

\section{Tabel 5.}

Hasil Observasi Uji Coba Lapangan Skala Kecil

\begin{tabular}{|c|c|l|}
\hline No. & \multicolumn{1}{|c|}{ Nama Siswa } & \multicolumn{1}{c|}{ Hasil Observasi } \\
\hline 1 & Rani & $\begin{array}{l}\text { Hari ke 1: penasaran dengan media yang dibuat oleh peneliti, ingin } \\
\text { tahu cara permaianan media, dan mulai memahami cara permainan } \\
\text { media. } \\
\text { Hari ke 2: mulai mengerti cara menggunakan media, menemukan } \\
\text { banyak jawaban yang benar, senang ketika jawabannya benar. } \\
\text { Hari ke 3: mengerjakan soal dengan konsentrasi dan aktif dalam tanya } \\
\text { jawab. }\end{array}$ \\
\hline 2 & Anisa & $\begin{array}{l}\text { Hari ke 1: penasaran dengan media, mulai memahami cara permainan } \\
\text { media. } \\
\text { Hari ke 2: mencoba media dengan percaya diri, sabar menunggu giliran } \\
\text { bermain, dan senang ketika jawabnnya benar. } \\
\text { Hari ke 3: konsentrasi dalam mengerjakan soal. }\end{array}$ \\
\hline 3 & Indi & $\begin{array}{l}\text { Hari ke 1: penasaran dengan media, mulai memahami cara permainan } \\
\text { media, dan sangat antusias. } \\
\text { Hari ke 2: membantu teman yang jawabannya salah, tidak sabar } \\
\text { menunggu giliran bermain, dan suka dengan tantangan soal. } \\
\text { Hari ke 3: berhati-hati dalam mengerjakan soal dan aktif bertanya. }\end{array}$ \\
\hline
\end{tabular}




\begin{tabular}{|c|l|l|}
\hline & & $\begin{array}{l}\text { Hari ke 1: terlihat bingung, belum ada kemauan untuk mencoba media, } \\
\text { dan masih butuh pendampingan ketika bermain media. } \\
\text { Hari ke 2: masih belum mau mencoba dengan sendirinya masih dalam } \\
\text { bimbingan peneliti, terlihat senang menggunakan media, dan berusaha } \\
\text { menyelesaikan soal. } \\
\text { Hari ke 3: sudah mau mencoba media sendiri meskipun lama dalam } \\
\text { menjawab soal. }\end{array}$ \\
\hline 5 & Fitriyah & $\begin{array}{l}\text { Hari ke 1: penasaran dengan media yang dibuat oleh peneliti, ingin } \\
\text { tahu cara permaianan media, dan mulai memahami cara permainan } \\
\text { media. }\end{array}$ \\
\hline $\begin{array}{l}\text { Hari ke 2: tidak sering bertanya dan berusaha menyelesaikan soal. } \\
\text { Hari ke 3: serius dalam menyelesaikan soal dan aktif bertanya. }\end{array}$ \\
\hline 6 & Hasan & $\begin{array}{l}\text { Hari ke 1: penasaran dengan media yang dibuat oleh peneliti, ingin } \\
\text { tahu cara permaianan media, mulai memahami cara permainan media. } \\
\text { Hari ke 2: sabar menungau giliran untuk bermain dan tidak mau } \\
\text { diganggu saat bermain. } \\
\text { Hari ke 3: kurang teliti dalam mengerjakan soal. }\end{array}$ \\
\hline
\end{tabular}

Dalam penelitian ini, peneliti menggunakan langkah-langkah penelitian dan pengembangan yang sudah dimodifikasi, terdiri dari: 1) potensi dan masalah, 2) perencanaan, 3) desain produk, 4) validasi produk, 5) revisi produk, dan 6) uji coba produk. Untuk mendapatkan inforamasi masalah yang terjadi di kelas II, dilakukan wawancara kepada guru kelas II dan siswa kelas II SD serta melakukan observasi ketika pembelajaran berlangsung di kelas II. Hasil wawancara dan observasi dijadikan dasar untuk membuat kuesioner analisis kebutuhan tentang media pembelajaran. Berdasarkan hasil kuesioner analisis kebutuhan, peneliti mendesain pengembangan media pembelajaran sesuai dengan kebutuhan di kelas II. Pengembangan media pembelajaran dalam penelitian ini yaitu media Malongka (mari lompat angka) materi operasi bilangan. Media pembelajaran tersebut terdiri dari 1) banner Malongka, 2) kartu soal, 3) lingkaran angka dengan warna biru, merah, kuning, dan hijau, 4) simbol operasi hitung.

Setelah media pembelajaran selesai dikerjakan, peneliti melakukan validasi produk kepada dosen ahli dan guru kelas II untuk menilai kelayakan pengembangan media. Berdasarkan hasil validasi produk, diketahui bahwa media yang dikembangkan sudah termasuk kategori sangat baik dengan skor validasi produk yaitu sebesar 3,3. Namun, perlu ada perbaikan di beberapa bagian serta penambahan komponen supaya lebih menarik dan memudahkan siswa dalam menggunakan media tersebut. Selanjutnya, peneliti melakukan revisi produk sesuai dengan saran atau masukan yang diperoleh dari hasil validasi produk kepada dosen ahli dan guru kelas II. Setelah produk direvisi, peneliti melakukan uji coba produk kepada enam siswa kelas II yang mendapatkan nilai rendah dalam mata pelajaran matematika.

Pada saat melakukan uji coba produk, siswa terlihat antusias dan tertarik belajar penjumlahan, pengurangan, perkalian, dan pembagian dalam menyelesaikan soal open-ended dengan menggunakan 
media pembelajaran. Setelah diberikan penjelasan tentang cara permainan media pembelajaran, siswa mencoba menggunakan media secara bergantian, mencoba menyelesaikan soal open-ended penjumlahan, pengurangan, perkalian, dan pembagian dengan menggunakan media pembelajaran. Kemudaian siswa menjawab soal open-ended yang tersedia pada kartu soal. Selama siswa mencoba menggunakan media pembelajaran, siswa tidak kesulitan menggunakan media walaupun medianya besar untuk melompat.

Dalam penelitian ini, peneliti melakukan pretest dan posttest kepada enam siswa untuk mengetahui kemampuan siswa sebelum dan sesudah menggunakan media pembelajaran. Rata-rata dari hasil pretest yaitu sebesar 39 dan rata-rata dari hasil posttest menunjukkan kenaikan 89 . Terdapat peningkatan pada rata-rata hasil pretest dan posttest sebesesar 50 atau presentase kenaikannnya yaitu sebesar $128,2 \%$. Dengan demikian, media pembelajaran ini sudah melalui uji validasi produk dan uji coba produk skala kecil di sekolah.

Berdasarkan hasil penelitian Nugraha (2016). Kelayakan Media Permainan Engklek sebagai Media Pembelajaran Pada Materi Sistem Pencernaan Makanan. Penelitian ini bertujuan untuk menentukan validitas, kepraktisan, dan keefektifan media permainan Engklek pada materi sistem pencernaan makanan. Hasil penelitian menunjukkan bahwa validitas setiap indicator memperoleh skor $\geq 61$ pada validitas 1 dan 2 , kepraktisan karena keterlaksanaan pembelajaran mencapai $\geq 81 \%$ dan respon "Ya" pada angket respon siswa mencapai $\geq 61 \%$, keefektifan siswa mencapai ketunyasan belajar ranah kognitif dengan nilai $\geq 2,85$ sebesar $75 \%$ dan skor aktivitas keterampilan komunikasi mencapai nilai $\geq 61$.

Penelitian yang kedua oleh Suwarto (2017). Strategi pembelajaran operasi bilangan dengan benda konkrit. Penelitian ini bertujuan untuk mengasosiasikan secara konkrit dari setiap operasi bilangan sehingga mampu dipahami secara mudah oleh siswa. Hasil penelitian yang didapat dari pembelajaran melalui benda konkrit menunjukkan bahwa 84,21\% untuk operasi penjumlahan dan pengurangan $65,79 \%$ untuk operasi perkalian $39,47 \%$ dari operasi pembagian dari jumlah sisiwa sebanyak 38 siswa dapat menguasai materi dengan baik.

Penelitian yang ketiga adalah penelitian yang dilakukan oleh Nurlita (2015). Pengembangan Soal Terbuka (Open-Ended Problem) pada Mata Pelajaran Matematika SMP Kelas VIII. Bertujuan untuk menghasilkan soal terbuka (Open-Ended Problem) pada pelajaran matematika SMP kelas VIII yang valid dan memiliki karakteristik soal yang baik. Hasil penelitian menunjukkan berdasarkan hasil uji lapangan, kemampuan berpikir kreatif siswa berada pada kemampuan kelancaran dan keterincian, sedangkan prestasi belajar siswa mencapai kategori positif dan soal terbuka (Open-Ended Problem) yang dikembangkan adalah layak untuk digunakan. 


\section{KESIMPULAN}

Pengembangan media dalam penelitian ini adalah mengembangkan media berbentuk banner untuk menyesesaikan soal open ended kompetensi penjumlahan, pengurangan, perkalian, dan pembagian di kelas II SD. Pengembangan media tersebut bernama media malongka (mari lompat angka). Ciri menarik dari media ini adalah siswa dapat belajar dengan bermain yaitu melompat angka, dapat digunakan pada berbagai macam kompetensi, membantu siswa menemukan berbagai macam proses jawaban dengan satu hasil.

Media malongka ini memiliki kualitas yang sangat baik dengan hasil rata-rata validasi media yang diperoleh yaitu sebesar 3,3. Efektifitas dari penggunaan media ini dapat dilihat dari segi kognitif dan afektif. Untuk segi kognitif atau pengetahuan dapat dilihat rata-rata hasil pretest 6 siswa hanya diperoleh skor sebesar 39 sedangkan pada rata-rata hasil posttest 6 siswa mengalami kenaikan 89 . Terdapat peningkatan pada rata-rata hasil pretest dan posttest sebesar 50 atau prsentase kenaikannya yaitu sebesar $128,2 \%$. Untuk segi afektif atau sikap, siswa terlibat aktif di dalam proses pembelajaran, berkonsentrasi dalam mengerjakan soal, kreatif menemukan berbagai macam jawaban dapat menyeselaikan soal open ended dengan benar, dan senang ketika belajar menggunakan media.

Berdasarkan hasil penelitian yang telah dilakukan bahwa media malongka dapat menyelesaikan soal open-ended pada materi operasi bilangan, diharapkan media malongka dapat digunakan untuk materi lain dan mengembangkan media ini pada mata pelajaran yang lain.

\section{DAFTAR PUSTAKA}

Achroni, K. (2012). Mengoptimalkan Tumbuh Kembang Anak Melalui Permainan Tradisional. Yogyakarta: Javalitera.

Isrok’atun, R. A. (2019). Model-Model Pembelajaran Matematika. Jakarta: Bumi Aksara.

Iswinarti. (2010). Nilai-nilai terapiutik permainan tradisional. Psikologi, Fakultas Malang, Universitas Muhammadiyah, 6(3), 1-16.

Khoriyani, R. P. (2019). Penerapan Pembelajaran Open Ended Pada Operasi Dasar Bilangan Bulat di Kelas VII SMP Negeri 3 Pontianak. Jurnal Pendidikan dan Pembelajaran Khatulistiwa, 8(3), 110.

Lestari, K.E. dan Yudhanegara, M. . (2015). Penelitian Pendidikan Matematika. Bandung: Refika Aditama.

Nugraha, H. S. (2016). Kelayakan Media Permainan Engklek Sebagai Media Pembelajaran Pada Materi Sistem Pencernaan Makanan. Pensa E-jurnal: Pendidikan Sains, 4(3), 1-7.

Nurlita, M. (2015). Pengembangan Soal Terbuka (Open-Ended Problem) pada Mata Pelajaran Matematika SMP Kelas VIII. Pythagoras: Jurnal pendidikan Matematika, 10(1), 38-49. https://doi.org/10.21831/pg.v10i1.9106

Sugiyono. (2016). Metode Penelitian Pendidikan Pendekatan Kuantitatif, Kualitatif, dan R\&D. 
Bandung. Penerbit Alfabeta.

Suharmanto. (2015). Pengembangan Media Pembelajaran Papan Hitung Pembagian Pada Mata Pelajaran Matematika Sekolah Dasar Kelas 2. jurnal teknologi pendidikan, IV(1), 165.

Suwarto, S. (2017). Strategi Pembelajaran Operasi Bilangan Dengan Benda Konkrit. UNION: Jurnal Ilmiah Pendidikan Matematika, 5(3), 285-294. https://doi.org/10.30738/.v5i3.1437

Zainal, A. (2012). Penelitian Pendidikan Metode dan Pradigma Baru. Bandung: PT REMAJA ROSDAKARYA. 